Revue Française de Civilisation Britannique

\title{
BBC Drama and the Politics of Production 1955-66
}

Les Fictions à la BBC et la politique de la production (1955-1966)

Joy Leman

\section{(2) OpenEdition}

\section{Journals}

Electronic version

URL: https://journals.openedition.org/rfcb/7642

DOI: $10.4000 /$ rfcb.7642

ISSN: 2429-4373

Publisher

CRECIB - Centre de recherche et d'études en civilisation britannique

\section{Electronic reference}

Joy Leman, "BBC Drama and the Politics of Production 1955-66 ", Revue Française de Civilisation Britannique [Online], XXVI-1 | 2021, Online since 05 December 2020, connection on 06 January 2022. URL: http://journals.openedition.org/rfcb/7642 ; DOI: https://doi.org/10.4000/rfcb.7642

This text was automatically generated on 6 January 2022.

\section{(c) (i) $\odot$}

Revue française de civilisation britannique est mis à disposition selon les termes de la licence Creative Commons Attribution - Pas d'Utilisation Commerciale - Pas de Modification 4.0 International. 


\section{BBC Drama and the Politics of Production 1955-66}

Les Fictions à la BBC et la politique de la production (1955-1966)

Joy Leman

\section{Introduction}

1 The British Broadcasting Corporation's name suggests an institution encompassing a national entitlement, for every citizen. However, history shows an uneven development in terms of representation of certain groups, both inside and outside the organisation, a development linked also to changes in society. In this article I shall look at the BBC during the growth period of the 1950s and 1960s, focussing on interlinked issues of class and gender in employment, production processes, and representation. Experiences and voices from inside broadcasting, including oral history testimonies will provide insights into the policies and practices of the BBC.

2 According to Smith,

the broadcasting institution is an unelective [sic] power centre, which becomes,

because of its connections with its society, an arbiter of the culture, a subtle patron

of politics, a steersman of the entertainments industry in all its forms. ${ }^{1}$

The BBC has both reflected and reinforced cultural, social, and political mores in British society over the decades, and an initial look at the structure and history of policy making at the $\mathrm{BBC}$ shows an organisation shaped by the dominant ideological and political perspectives of its time. A significant factor in this was that of - new men on the block - managerial figures making policy decisions which changed the direction of the BBC. The results, prompted partly by survival strategies in the face of competition, included efforts to address a broader section of the population, with fundamental shifts in the representation of class and, to some extent, of women.

In this context, two key aspects of this expanding period in television programming will be examined. The first example touches on employment conditions for women at 
the $\mathrm{BBC}$, together with a consideration of programmes aimed at women viewers, themed largely by an ideology of domesticity, with few changes in the mode of address. Secondly drama production is examined in some detail, on the grounds that this period marks a significant change of direction for this popular genre, both in terms of the role of practitioners, writers, producers, directors, and the shift towards a discourse of political and social change in the wider framework.

5 A creative element predominant in enlarging the scope of the $\mathrm{BBC}$ was that of the practitioners in prompting alternative perspectives for perceptions of gender and of social class. These issues continue to have resonance, both historically and in the contemporary context. Significantly, there have been recent calls from within the BBC regarding key issues of gender and of racial equality. These demands have been partly prompted by the Black Lives Matter movement against racism and the MeToo movement against gender discrimination. A clear indication of continuing discrimination against women employees, is the recent revelation that prominent female presenters in BBC television in the present day, have been paid less than their male colleagues doing the same work. ${ }^{2}$

\section{Women at work, programmes, images of domesticity and class}

6 Unequal pay has been the unspoken norm in society as well as in the BBC even for women employed in the upper echelons. There have always been women in administrative roles at the $\mathrm{BBC}$ - as organisers, or with responsibility for certain programme categories, both in radio and television, but, normally, fewer than men. ${ }^{3} \mathrm{~A}$ recent account by Kate Murphy, with experience as a producer on the $\mathrm{BBC}$ radio programme Woman's Hour, has shown how "women "oiled" the machine of the $B B C$ as well as [revealing] their capacity to create, to innovate and to lead'. ${ }^{4}$ She points out that women initially constituted approximately one third of established BBC staff, but had lower wages and expectations of promotion than male employees, were not included in the major decision- making body - the Control Board, and were subject to the 'marriage bar. This meant that during the years 1932 - 1944, any woman employed by the BBC who married, either had to resign or be dismissed. However, occasional exceptions were made at the time, depending on class and income, as indicated in this memo marked "strictly private and confidential".

The Corporation has been guided by the belief that only an exceptional woman, with adequate material resources, can perform her duties satisfactorily as a whole time servant of the Corporation while attempting also to fulfil the cares and responsibilities of a young family. ${ }^{5}$

7 Nevertheless, there were notable, if privileged, women producers in $B B C$ radio, who made a difference, and introduced the idea of programmes directed towards a female audience. Even in wartime, the argument had to be made, prioritising urgent objectives in the programme address, and attempting to overcome continuing prejudice of male executives. Janet Quigley was a producer, within the Talks Department who later went on to produce Woman's Hour in the 1950s but in wartime, she had to argue for the validity of programmes aimed at women, arising from the need for women in the workforce. ${ }^{6}$ Mode of address regarding social class was, in her view, crucial to the effectiveness of these programmes. 
There still seems great need on the one hand to present industry to the workers in a way that will somehow fire their imagination and enthusiasm, and...to use every possible means to make factory workers feel that they are appreciated, and that their share in the war effort is fully recognised...Women at War can help on both these. $^{7}$

Programmes included Women can't do it ${ }^{8}$ (1942), produced by Winifred Holmes and Mostly for Women ${ }^{9}$ also produced by Janet Quigley, and focussed on working women. Internal correspondence shows an unusual consideration for listener participation and for an acceptable class voice, which should be not too "posh" or patronising. ${ }^{10}$

However,, the situation changed with the government demand at the end of the war for women to return home. This was reflected in BBC programming. There were notable women appointed in reorganisation at this time, including Mary Adams, who was first Head of Talks in 1946, and also Mary Somerville, talks controller in the 1950s. Nevertheless, programmes addressing a female audience in 1950s television emphasised 'hearth and home', presented in the habitual tones of the time, the upperclass voice. For example,the long-running series, 'About the Home' launched on BBC television in 1952, focussed on practical issues of home making, with advice concerning dogs, flower arranging, cookery, health and keep-fit, including a didactic presentation on kitchen hygiene. ${ }^{11}$

The possibility for change came with the creation of a separate department for Women's Programmes, an innovation approved by the Director of Television Broadcasting in 1955 with the proviso that the newly appointed editor of Women's Programmes, Doreen Stephens, should consult the Head of Talks on any items dealing with politics or current affairs. Family Affairs, broadcast from 1955 to 1961, was aimed at 'mothers with young children'. Doctors, clergyman, and Justices of the Peace were presented as experts, giving advice on family problems. The programme was frequently organized around problems sent in by viewers.

11 For Women: Leisure and Pleasure, on television from 1951, gave more time to flowerarranging, embroidery and antiques, but also 'celebrity' guests from contexts of theatre, music, literature and fashion. On the $11^{\text {th }}$ August 1953, for example, the programme invited Adrian Digby, keeper of the British Museum, to speak, and featured a section on learning French phrases for holidays. On the $28^{\text {th }}$ September 1958 , lessons in sketching, and the new designs in Irish linen, were at the centre of the programme.

Competition from commercial television after 1955 prompted BBC attempts to target a range of female viewers with slots, in the TV series Mainly for Women. This included a 'tea dance', a magazine programme for older women, another for younger married women, and consumer advice programmes chaired by Lady Isabel Barnett. ${ }^{12} \mathrm{The}$ BBC "best dress dense" competition also featured, this being a national competition to find the woman viewer with the best dress sense.

13 The concept of women's interests, while shaped by the ideology of domesticity, was also based on assumptions of financial and social advantage, in both employment and lifestyle. Controller of Programmes, Cecil McGivern, was critical of the programmes, and a fundamental misjudgement is also implied by Women's Programmes Organiser, Robin Whitworth, responding to a BBC Viewer Research Report.

Bearing in mind that over fifty per cent of the actual and potential viewers of Women's Programmes left school at the age of fourteen or less, do the programmes show signs of any class-consciousness or bias in either direction? With regard to 
social class and income group, are the programmes appropriately tuned to the audience? ${ }^{13}$

14 This critical comment, suggesting that these programmes were missing the target audience, is reinforced by BBC Viewer Research showing that only 12 to 15 per cent of the potential audience of women were 'fairly regular viewers'. ${ }^{14}$

\section{A Dramatic start for television. What tensions and debates accompanied the rise of television?}

15 The newer technology of television, which had crept onto the scene in the 1930s, was given little credibility initially by the BBC institutional hierarchy since the official concept of public service was inextricably linked to radio.. This perspective continued, with a bureaucratic structure, based on a government Civil Service model, enforcing a cultural hegemony under the leadership of William Haley, the Director General, 1944 -1952 .

16 The government-commissioned Hankey Report, of 1945, supported the development of a BBC television service, but top managers were not convinced. Sir William Haley's concern that television might replace radio in the home, with a drop in cultural standards, resulted in limited staffing and resources for television. ${ }^{15}$ Michael Barry, a drama producer at the time, defined the position of television as "an ugly duckling, unwelcomed and of doubtful character ... of no importance" ${ }^{16}$ Inequality in division of funding between radio and television was exacerbated by the patronising attitude and cultural disdain by those in charge at the BBC. This battle for the legitimacy of television only changed when Ian Jacob was appointed as Director General to replace Sir William Haley in 1952.

The voices from BBC employees in support of television were those of pioneers in the field, including Maurice Gorham, the first Head of Television. Grace Wyndham Goldie, one of the few women in a key position in the BBC at that time, foresaw the game changing importance of television, predicting as early as 1947, that "Television is a bomb about to burst". ${ }^{17}$ An alternative, radical, solution for wider distribution is shown in an internal memo invoking social class, lower-price TV sets, shared viewing, and a challenge to the popularity of cinema.

will the Government contemplate itself producing a cheap people's television set?...Would not a combination of communal viewing plus home viewing based on a properly balanced public service be healthier, more educative, and more enlightening than a service based on Hollywood.... ${ }^{18}$

However, the substantial take-up of television viewing for the coronation in $1953 \mathrm{had}$ a huge impact, with families and neighbours coming together for collective viewing in the home. In Britain, $56 \%$ of the population (20 million) watched the coronation on television. ${ }^{19}$ This was a springboard for the BBC Five Year Plan for television expansion including more studios, regional facilities and transmission relay stations, a prestigious Television Centre, an additional channel - BBC2, and future colour transmissions. By 1954, nearly one in three families in UK had television sets. ${ }^{20}$ This reflects the post war period of relative economic stability, industrial expansion and an improvement in living standards. Broadcasting policies, regional development plans and competition for resources depended, nevertheless, on the invisible network of organisers, secretaries, producers, directors, writers, studio managers, costume designers, make- 
up artists and camera operators, responsible for the continuity of programmes broadcast. But there was continued differentiation of wages or salary linked to class and gender. In terms of employment possibilities, the BBC dominated the field as the only television organisation in Britain until 1955, when ITV, the commercial channel, was authorised to start.

\section{Drama productions} the Prince of Morocco in the Merchant of Venice, forgot his lines and fainted in full view. It was the sheer nervousness and he conquered it in the repeat performance two days later. ${ }^{22} \mathrm{~A}$ closer look at television drama production at this time highlights the positives and negatives of the $\mathrm{BBC}$ - the institution, the icon, the national cultural microchip of the time. Prior to the arrival of recording technology, television output was 'live' which brought the possibility of avoiding official approval.'. Cultural connotations linked the uniqueness of live television drama to live theatre, particularly at a time when classical literature adaptations were predominant. The work of the cameraman - never camerawoman - was crucial, but anonymous, rarely given recognition for the creative contribution which in cinema is credited as 'cinematographer' but at the BBC was unnamed. Michael Barry, drama producer at the time describes cameraman, Ted Langley as 'an enthusiast...capable of being an artist in his own right' particularly in his use of difficult camera technology, using close-ups for a production dealing with the murder of Alexander the Great. ${ }^{23}$

When Michael Barry was made Head of BBC Television Drama in 1952, he used his earlier, theatre experience to encourage writers to work in the expanding field of television drama. However, $\mathrm{BBC}$ resources for television were still meagre, as compared to radio which had the 'lion's share'. Michael Barry captures the attitude of BBC hierarchy at the time

"The intellectual disdain for television and the lack of sympathy with its needs and aspirations were culpable follies that led to the entrenchment of those who were devoted to its furtherance but were denied support". ${ }^{24}$ drama, together with training for television designers and producers, organised by 
experienced producer, Royston Morley, as well as a new Central Script Unit Section which started in 1955.

\section{'Normal' and 'abnormal': BBC Sci fi}

The 1950s also saw the arrival of new kinds of drama. Nigel Kneale, the writer was a key mover in the project to encourage new writers for television. The science fiction drama, the Quatermass Experiment written by Nigel Kneale and produced by Rudolph Cartier, broadcast in 1953 marked an important innovation towards a British popular culture genre for television. A serial format was used, which would become an essential strategy for winning and keeping regular viewers. The idea of quality viewing targeting a wider, working class audience was integral to this production. According to Cartier, the intention was 'to lift this production above the level of strip cartoons and magazine thrillers. ${ }^{25}$ Kneale, outlines his strategy of a differentiation of themes across the first two series. 'Instead of a normal world with one sinister element moving in it, as before, we have one normal protagonist (Professor Quatermass) moving in an increasingly abnormal world'. ${ }^{26}$

The three Quatermass series broadcast in 1953, 1955, and finally, 1958, show stylistic influences from cinema and radio as well as theatre, drawing high viewing figures, amounting to 21 per cent of the adult UK population.. Kneale links the technology of live broadcasting to the creative strategies adopted by writers and producers. "Because it was put out live you had, anyway, to put the emphasis on the characters - you simply couldn't launch into a load of special effects". ${ }^{27}$

Representation of women and class in these series have positive dimensions but with stereotypical tendencies. The female scientific assistants and researcher depicted in Quatermass and the Pit transmitted at peak viewing time in Dec1958 were mainly upper class and highly educated. They show, supposedly feminine, intuitive, perceptions concerning the sinister, alien environment, but also demonstrate extensive scientific knowledge. This combination emerges in the narrative as ultimately more useful than what is shown as typically masculine, rational, analysis which draws on the material, science- professor logic, expressed by Quatermass. ${ }^{28}$ The series concludes with a speech by Professor Quatermass of political significance and relevance to our present -day environment: 'Every war crisis, witch hunt, race riot, purge, is a reminder and warning. We are the Martians - if we cannot control the inheritance within us this will be their second dead planet'.

Changes in terms of class and female image in BBC television sci fi drama became apparent three years after the final Quatermass series. A for Andromeda presents a narrative critical of a hegemonic framework of political, military and technological power in Britain exerting pressure on a group of scientists in a highly advanced laboratory. Familiar themes, both then and now, were presented, concerning uses and control of new technology, the role of computers, together with radio telescopes, and directions for future, space based, laboratory developments. Plot and dialogue explored issues concerning science, philosophy and politics, plus a combative discourse on gender, sexuality and social class. ${ }^{29}$ Three of the leading characters were female, including the professional scientist and the research assistant - who evolves into an android of classical beauty. The two young male research scientists are depicted as graduates from 'red brick' universities - the new post war non elitist educational institutions in Britain which welcomed students from less privileged, working class, 
back grounds. One of the producers, Michael Hayes explains that the part of the leading professor was originally a male character but he cast it as a female role "because I wanted to set the scene more firmly in 1970, when I imagine there will indeed be far more women in positions of responsibility'. ${ }^{30}$

\section{$\mathrm{BBC}$ drama and the arrival of competition}

Drama played a key role in the BBC's reaction to the arrival of commercial television. This event in 1955 "shook up the gentlemanly aesthetic and the cultural discourse of the patrician public service institution". ${ }^{31}$ BBC internal indicators included a newsletter entitled The Competitor, marked strictly confidential and published regularly in 1955-56. The institutional response to the 'shock waves' of dealing with a seemingly successful competitor, was shown in management changes including the appointment of Hugh Greene as BBC Director General in 1960 prior to the Pilkington Report of 1962 on the future roles of both BBC and ITV. He authorised a programme of restructuring with new team managers and new directions in the cultural discourse of $\mathrm{BBC}$ television programmes. Economic and ideological factors motivated fresh approaches in setting out to 'win back' the mid-evening audience which had switched over to the commercial channels, and, in particular to the drama on offer from the ITV companies. The guarantees of 'quality' broadcasting and high culture provision integral to the BBC's function as public service broadcaster were being challenged by the successful drama productions of the 'competitor'. Not only was the reputation of the BBC at stake with its perceived potential to change and modernise, but there was the threat to the license fee, the financial source of all BBC activities. The license fee was demanded from everyone who owned a television set, but the $\mathrm{BBC}$ appeared to be catering only for a minority of this audience,

Drama, therefore, constituted an important part of the BBC counter- attack to ITV in the need to attract the mid evening audience. A strategic move in 1963 by BBC top management resulted in 'poaching' the Head of the most successful Drama Department in British commercial television at the time - Sydney Newman, a Canadian who had been producer and Drama Supervisor at ABC TV and innovator of the famous ITV series, Armchair Theatre. His egalitarian approach is shown in a frank statement, with his views of British television drama.

The plays didn't seem to know who in the hell they were talking to and the TV drama series didn't have any grasp of who its audience was. So I said we would have an original play policy with plays that were going to be about the very people who owned TV sets - which is really a working-class audience. ${ }^{32}$

Newman restructured the organisation of $\mathrm{BBC}$ drama, introducing a mediating role for a Story Editor and team- work involving producer, director and writer. The new structure was partly motivated by Newman's awareness of future demands, including plans for BBC2. The Drama 'Group' with Sydney Newman as Head, contained three divisions, series, serials and plays, each with its own Head, different objectives, budget and resources. The series was classified as popular, while the single play could encompass cultural representation from the historical to the contemporary. The 'one off' drama was preferred by Newman for classical reasons of completeness of artistic intentions by the playwright. However, given the imperatives of winning and retaining audiences from the competitor, he also encouraged the trend towards production of series and serials. The categories of drama delineated by Newman had already shown 
new directions, but the trend would become clearer, with fewer stereotypical representations of women and greater authenticity in representation of working- class context, narrative, and personage. Episodic drama as short bursts of entertainment , was already part of the strategy to reach a wider, working class public.. A regular series of episodes geared to increased family viewing, began in April 1954 with The Grove Family, which became a long running soap opera (feuilleton\}. A police series, Dixon of Dock Green, featuring an avuncular, friendly neighbourhood police constable, started in 1955 , also appealing to regular viewers. However, by 1962, a more dynamic and realistic image of the police emerged in the long running series $Z$ Cars. This was an indicator of the new trend during intensive years of change in form and content even before the arrival of Sydney Newman. Viewing figures for the series showed an increase from 8.75 million at the start, which gradually 'settled down to an audience of nearly 12 million' according to the Director General of the BBC. ${ }^{33}$

\section{Angry young writers and directors}

$$
\text { management structures was also driven by movement in the social, political framework }
$$
of the time.

er context of dissatisfaction had emerged earlier, exacerbated by the politica events of 1956 with the invasion of Hungary by the Soviet Union and of Suez by Britain and France, as well as a major anti-war movement in the Campaign for Nuclear Disarmament. According to John Russell Taylor writing soon after,

protest was in the air, and the mood of the country, especially that of young England, veered sharply from the preciosity and dilettantism which had been in vogue, ... to one of grim political consciousness. In Look back in anger and Colin Wilson's The Outsider... as well as in the extrovert, disenchanted novels of John Wain and Kingsley Amis, the under-forties as well as many of the under- thirties, found a rallying point.... ${ }^{34}$

The South East England upper class voice of authority, naturalised after years of reinforcement in the mainstream media, was being neutralised. In the atmosphere of cultural contestation which became the 'spirit of the age', plays and novels influenced an emerging generation of writers for television drama, particularly as dramatic constructions, including theatre plays had become the unlikely expression of revolt and criticism aimed at the dominant upper class mores of society. This included challenges represented by Joan Littlewood and the Stratford East Theatre Workshop.

In this context, the search for new material and new writers increased with the expansion of BBC television transmission hours and the arrival of ITV. Even with the success of certain television playwrights, there was, initially, a shortage of writers. One of the few women writers for television, Elaine Morgan, observes "It was a sellers' market. They sent teams round to provincial centres urging - pleading with aspiring writers to try their hands at television". ${ }^{35}$ This view is underlined by the director, Maurice Hatton: "Get the script, then get the director, the writers were primary". ${ }^{36}$ Arthur Swinson, an experienced writer for television drama suggested that British writers should learn from the example of Paddy Chayevsky, the American dramatist, and should aim for more authenticity. 
are more fascinating stories in the lives of apparently quite ordinary people than in most fiction, and television is an excellent medium for telling them...television needs the writer even more than he needs television." ${ }^{37}$ This experimental period also involved writers and producers interested in dramatized story documentary, described by one of the few women producers at the BBC, the director/writer, Caryl Doncaster, as "one of the few art forms pioneered by television" ${ }^{38}$ These programmes were broadcast live from the studio, over a ten -year period, under the control of BBC Documentary Department headed by Paul Rotha. The series dealt with a range of social issues concerning children and adolescents, youth crime and its treatment, industrial relations, women at work, prison conditions and post prison treatment. Investigative journalism techniques were combined with the work of writers of drama, capturing the authenticity of everyday life. 'Return to Living', written and produced by Caryl Doncaster, concerned life after prison, using advice from an ex- prisoner to reproduce the actual voice and behaviour of someone newly released. The 'non acting' of the actor was essential to convey 'the person he is portraying' in the final studio production. The repertoire of the present, moving from literary adaptations, onto the immediacy of everyday life, put the focus on class, dialects and regional accents, with the 'rediscovery of the eloquence of the vernacular'. ${ }^{39}$ Drama output from BBC Wales, presented narratives of Welsh working -class life, as in Going like a Fox written by Alun Richards, broadcast nationally in 1960. Liverpool/ Welsh writer and ex coal miner, Alun Owen, had worked as an actor in $\mathrm{BBC}$ drama from the Welsh region, and was also a prolific writer for theatre, $B B C$ radio and television during this period. In his view:

Dialogue is very important, that's why people say that television is the writer's medium. I like writing for television because of the audience. Most people have a television set, but few and far between are the people who go to the theatre. The vast majority of people in this country are working class people. I am of and from that class and they are the people that I write for. ${ }^{40}$

Similarly, John Arden, in collaboration with Margaretta D'Arcy, wrote for theatre, radio and television, conveying issues of class, in a regional context with a mixture of verse, prose and non-realistic presentation of songs and ballads, with significant historical backgrounds, as in 'Soldier, Soldier', BBC television, Feb. 1960. A sense of urgency among this first generation of class-conscious, university educated, writers for television, is conveyed by Don Taylor, writer and BBC television director:

I wanted to get onto the screen radical, questioning work, which at that time was likely to be a product of the upsurge of interest in the real life of the working class from playwrights who knew that background. ${ }^{41}$

Class, community, but also social fragmentation and education became central themes in BBC television drama of the time. Where the Difference Begins, a prominent example of this, was a controversial, political drama, written by David Mercer, broadcast live, and not recorded 1961/62. Troy Kennedy Martin gives an insight into different BBC responses to the writer. His first play for television, Incident at Echo Six, produced by Gilchrist Calder, broadcast in 1958, concerned National Servicemen in the Cyprus conflict. Subsequently he was given a one -year contract as screenwriter/adapter in the Drama Department, an experience which highlighted the difference between institutional structure and creative input in his comment that "In television the writer is a functionary - and part of a team". ${ }^{42}$ Team- work was significant in the 1964 success of Diary of a Young Man, using non- naturalistic style, with direct address to camera by a young working- class lad. This 6- part drama, written by Kennedy Martin and John 
McGrath, included Ken Loach and John McTaggart as directors and producer. Kennedy Martin saw himself and McGrath as part of "a bigger gene pool", influenced by the political and intellectual discourse of the time, but working through the tightly structured institutions of television. ${ }^{43}$ Julia Jones was part of that 'gene pool', and author of four plays broadcast in the Wednesday Play series. A Designing Woman broadcast in 1965, concerns a young woman in Lancashire, with explicit instructions in the script, concerning the regional voice "rich and rolling Lancashire accent" which Jones considered essential for the authenticity of her characters. ${ }^{44}$

The majority of writers, directors and producers for BBC Television drama were male and white. However, Irene Shubik worked on many drama productions, becoming story editor and producer on the renowned BBC TV series Wednesday Play and Play for Today broadcast 1964 - 1972. In her book, she shows that writers, producers and directors in this output of more than 270 plays, were mainly men. Twelve women writers are listed, but among producers, Shubik was almost unique, and responsible for producing at least 70 of these dramas. ${ }^{45} \mathrm{Errol}$ John, originally an actor and director, from the Caribbean, may have been the only writer in this series from an ethnic minority group.

41 Both Elaine Morgan and Irene Shubik maintained, when talking to me, that at the start of their careers, class was more crucial than gender "I was never conscious of any real discrimination... not from above, strangely it was later on." ${ }^{46}$ Nevertheless, for writers, living standards were precarious, with intermittent patterns of employment, often on a freelance basis, working from home, in isolation, and not necessarily part of the final production process. They were poorly represented within what became a highly individualised competitive framework leaving the writer vulnerable in terms of contracts and fee scales. This was in contrast to other, regular, behind the screen workers where technician-based unions shared a common working environment and the scale of organised power to close down the system if necessary. Collective representation through Trade Unions had been difficult, as initially, the BBC would only negotiate with the inhouse organisation - the BBC Staff Association. The emergence of The Writers Guild in 1955 resulted in some improvement, but according to Lewis Greifer, a script editor and writer "In the early days it was dog eat dog...The Guild altered the whole status of TV writing... The Guild stopped people working for nothing". ${ }^{47}$

The success and popularity of BBC television drama during the 1960s derived partly from what Graham Fuller describes as

the sense of ferment among the young, primarily socialist writers and directors gathering at the $B B C$ under the leadership of the ebullient Canadian Sydney Newman'.... who, by launching the Wednesday Play in 1964, 'would redefine the parameters of the British television play both in terms of political content and dramatic potential. ${ }^{48}$

Issues of gender and class were central to this tipping point in the history of the BBC, shown particularly in the work of director, Ken Loach and producer, Tony Garnett. Up the Junction, broadcast in 1965, as a Wednesday Play, was based on the novel by Nell Dunn, who collaborated with Loach on the script presenting a working class community in London, with the emphasis on women working -but also on the question of abortion, which at that time was illegal in Britain. As part of their strategy to foreground the immediacy of problems in everyday life, and utilising opportunities presented by innovative recording technology to reinforce authenticity, Loach and Garnett moved outside, away from conventional BBC studio- based drama, towards 
filming and hand-held camera in real locations, combining drama with documentary. This resulted in both negative and positive audience response, but also a retreat by BBC officials, including Sydney Newman, who cancelled the second planned screening of the play due to objections to the focus on abortion. ${ }^{49}$

The substantial social and political impact of BBC television drama from the Loach and Garnett team was confirmed in the 1966 screening of Cathy come home, depicting the dire situation of a family made homeless. This provoked widespread public reaction of shock, but also sympathy, particularly for the principal character of the mother. However, in the same year, there was the famous, total ban on the transmission of The War Game, another powerful drama, by Peter Watkins, dealing with possible consequences of nuclear war - this time considered by the authorities as too strong for British viewers.

\section{Conclusions}

In this brief survey of a chapter in the history of the BBC I have shown that during a significant period of change in the wider society, this major broadcasting institution had to compromise, restructure and adapt in terms of organisation, representation, and address to audience. The turning points outlined here include the launch pad of debate regarding the validity of television - the new technology intruder into the struggle for resources at the $\mathrm{BBC}$. The subsequent change of orientation was significant and extensive, from patriarchal, elitist, high culture institution with government approval for access to the nation, into a broadcaster with voices and images from the community at large -and a wider representation of class in one genre at least, drama, which was central to television programming. A long term, problematic issue, hidden from history, was the presence of women, initially employed in a multiplicity of roles at the $\mathrm{BBC}$, but thanks to recent research efforts, the invisible presences and past contributions of women at different levels within the $\mathrm{BBC}$ are currently coming to light. Programmes directed towards a female audience, however, were disappointingly limited and problematic in terms of stereotyping, with the exception of earlier examples of wartime radio broadcasts.

Changes in BBC management structures during the 1950s and 60s brought different attitudes and a transformation in some areas of programming. The substantial swathe of themes and ideas which swept across the schedules in drama output subsequently resulted in a visibility of class, gender and specific communities previously unacknowledged in the discourse of British broadcasting. Nevertheless, even within a relatively benign management framework, the judgement and integrity of production teams was questioned but measured against pressures of prospective competition and threats to established channels of finance..

The passage of ideas and their expression in form and content of BBC drama output of the time marked significant shifts in the dominant discourse. But whilst this era is renowned for boundary breaking, experimental drama, it was the ingenuity of writers and other practitioners which gave expression to this, together with the creative license of alternative methods of production linked to technological change utilised by production teams. Empirical sources, contemporary accounts from participants, have provided an essential key to further understanding of the history of the $\mathrm{BBC}$ during the 1950s and 1960s. 
However, whilst this was no golden age, and the dominance of men, as writers, producers or directors appears anomalous from present day perspectives, there is evidence of a more positive presence of women at the practitioner and story level. In the genre of drama discussed here, the working -class presence and voice showed expressions of creativity previously unexplored, communicating with a wider, working class audience. Nevertheless, the pressure to achieve greater equality continues, in terms of class, gender and ethnicity, both online and offline, in front of, and behind the $\mathrm{BBC}$ cameras.

\section{BIBLIOGRAPHY}

Bakewell, Janet and Garnham, Nicholas, The New Priesthood (London, Allen Lane, 1970).

Barry, Michael, From the Palace to the Grove (London, R.T.S. 1992).

Briggs, Asa, The History of Broadcasting in the United Kingdom, Volume IV, Sound and Vision (Oxford, Oxford University Press).

Caughie, John, Television Drama (Oxford, Oxford University Press, 2000).

Doncaster, Caryl, The Story Documentary in Paul Rotha (ed.), Television in the Making (London, Focal Press, 1956).

Fuller, Graham, (ed.), Loach on Loach (London, Faber and Faber, 1998

Goreham, Maurice, Sound and Fury (London, Percival Marshall \& Co., 1948).

Leman, Joy, 'Pulling our weight in the call-up of women': class and gender in British radio in the Second World War in Christine Gledhill and Gillian Swanson (eds.) Nationalising femininity (Manchester, Manchester University Press, 1996), pp. 109-118.

Leman, Joy, 'Programmes for women' in 1950s British Television' in Helen Baehr and Gillian Dyer (eds.) Boxed In: Women and Television (London, Pandora Press, 1987), pp.73-95.

Leman, Joy, 'Wise Scientists and Female Androids: Class and Gender in Science Fiction' in John Corner (ed.), Popular Television in Britain: studies in cultural history (London, British Film Institute, 1991), pp.108-124.

Leman, Joy, Capitalism and the Mass Media: Case Study of Women's Magazines and Radio Programmes 1935-55. M.Phil dissertation unpublished, University of Kent 1983.

Levy, MF, La television dans la république, Les Années 50 (Brussels, Editions Complexe 1999).

Murphy, Kate, Behind the wireless: A History of Early Women at the BBC, (London, Palgrave Macmillan, 2016).

Purcell, Jennifer J. Mother of the BBC: Mabel Constanduros and the development of Popular Entertainment on the BBC 1925-1957 (USA, Bloomsbury Academic, 2020).

Rodger I, Radio Drama (UK, Macmillan, 1982).

Seymour-Ure, Colin, The British Press and Broadcasting since 1945 (Oxford, Basil Blackwell, 1991). 
Shubik, Irene, Play for Today: The Evolution of Television Drama (London, Davis-Poynter, 1975).

Smith, Anthony, The Shadow in the Cave (London, Quartet,1976).

Swinson, Arthur, 'Writing for Television' in Paul Rotha (ed.), Television in the Making (London, Focal Press, 1956), p.43.

Taylor, Don, Days of Vision (GB, Methuen, 1990).

\section{Specialist Research Sources}

\section{BBC Written Archives Centre, Caversham, GB}

Note by the BBC, 1946

Audience Research Report RN/10, Viewers, Viewing and Leisure,1955.

Memo from Women's Programmes Organiser Robin Whitworth to Mr Mary Adams, Nov 1955.

Letter from R. Cartier to C. Moodie Information Division Air Ministry, 12.06.1953.

Nigel Kneale to Cecil McGivern, CP Tel., 5.11.1955.

Letter to Mary Morris from Michael Hayes, 7.06.1961.

Hugh Carlton Greene to George Brown MP, T16/734, 23.07.1962.

British Film Institute Library

Personal Interviews

Elaine Morgan, 2003. Maurice Hatton, 1995. Troy Kennedy Martin, 1994. Irene Shubik, 1995.

\section{NOTES}

1. Anthony Smith, The Shadow in the Cave (London, Quartet, 1976), p. 64.

2. Carrie Gracie, Equal, (London, Little, Brown Book Group, 2019).

3. Joy Leman, 'Pulling our weight in the call-up of women': class and gender in British radio in the Second World War, in Christin Gledhill and Gillian Swanson (eds.), Nationalising Femininity (Manchester, 1996), pp. 109-118.

4. Kate Murphy, Behind the Wireless, a History of Early Women at the BBC (London, Palgrave Macmillan, 2016).

5. BBC Internal Memo, headed: strictly private and confidential, BBC Written Archives, 15.08.1933.

6. Joy Leman, Pulling our weight in the call-up of women: class and gender in British radio in the Second World War, in Christine Gledhill and Gillian Swanson (eds), Nationalising Femininity, (Manchester, 1996), pp.109-118.

7. Janet Quigley to Director of Talks, 19.02.1942.

8. For example, the episode on 9 December 1942 is presented in the Radio Times as follows :" A Northern Ireland factory-worker, who used to sell flowers in a shop, describes her present job"

9. The entry in the Radio Times for the episode broadcast on 26 July 1942 read " ' Should men help in the house ?' Two men and two women talk it over »

10. Joy Leman. Unpublished M. Phil dissertation, 1983.

11. Joy Leman, Programmes for Women in 1950s British Television, in Helen Baehr and Gillian Dyer (eds.), Boxed In: Women and Television (London, 1987), pp. 81-82.

12. Ibid. p.84. 
13. Memo from Women's Programmes Organiser Robin Whitworth to Mrs Mary Adams (November 1955), BBC Written Archives,

14. BBC Audience Research Department, 7 November 1955, BBC Written Archives.

15. Ibid. p. 208.

16. Michael Barry, From the Palace to the Grove (London, Royal Television Society, 1992), p.133.

17. Ibid. p. 173.

18. Note by the BBC, (WAC, 1946).

19. Asa Briggs, Ibid., $p$

20. Audience Research Report R9/10, Viewers, Viewing and Leisure, (BBC WAC, 1955).

21. Janet Bakewell and Nicholas Garnham, The New Priesthood: British Television Today, (London, Allen Lane, 1970), p. 9.

22. Maurice Goreham, Sound and Fury, (London, Percival Marshall \& Co1948), p.2.

23. Michael Barry, From the Palace to the Grove, (London, Royal Television Society 1992) p. 141.

24. Ibid. p.22.

25. Letter from R. Cartier to C. Moodie Information Division Air Ministry, BBC Written Archives, 12.06.1953.

26. Nigel Kneale to Cecil McGivern, CP Tel, BBC Written Archives, 5.11.1955.

27. J. Petley, Interview with Nigel Kneale, Prime Time, Vol 1, N9, GB, 1984/85.

28. Joy Leman, Wise Scientists and Female Androids: Class and Gender in Science Fiction, in John Corner (ed.). Popular Television in Britain: studies in cultural history (London, British Film Institute, 1991) pp. 108-124.

29. Ibid.

30. Letter to Mary Morris from Michael Hayes, BBC Written Archives, 7.06.1961.

31. John Caughie, Before the Golden Age, in John Corner (ed.) Popular Television in Britain, (Britain, BFI) 1991.

32. Sydney Newman interview with John Wyver, Time Out, 6.4.1979.

33. Hugh Carlton Greene to George Brown MP, BBC Written Archives, T16/734, 23.07.1962.

34. John Russell Taylor, Anger and After, GB, 1966, pp. 33/34.

35. Elaine Morgan to Joy Leman, Personal Interview, 2003.

36. Maurice Hatton to Joy Leman, Personal Interview, 1995.

37. Arthur Swinson, Writing for Television, in Paul Rotha, ed, Television in the Making, Focal Press London 1956, p.43.

38. Caryl Doncaster, The Story Documentary in Paul Rotha (ed), Television in the Making. (London, Focal Press, 1956), p. 44.

39. I. Rodger, Radio Drama. UK, 1982, p.122.

40. Alun Owen Interview, Sunday Times, 30.03.1969.

41. Don Taylor, Days of Vision, (GB, 1990), pp. 86-87.

42. Troy Kennedy Martin to Joy Leman, personal interview, 1994.

43. Ibid.

44. Julia Jones Papers, Special Collections, British Film Institute Library.

45. Irene Shubik, Play for Today: The Evolution of Television Drama, (London, Davis-Poynter, 1975), pp. 59-84.

46. Irene Shubik to Joy Leman, personal interview, 1995.

47. Lewis Greiffer to Joy Leman, personal interview, 1996.

48. Graham Fuller, (ed.) Loach on Loach, (London, 1998) p.9.

49. Head of Drama Group, Television to C.P, Tel, 15.16.1966, BBC Written Archives Centre. 


\section{ABSTRACTS}

This paper offers a critical perspective regarding the British Broadcasting Corporation, briefly touching on the early years, the dominance of radio, and the struggle to obtain recognition and resources for television production. The management structures, policies and decision making of the $\mathrm{BBC}$ will be considered, with reference to consequences for practitioners and for the form and content of programmes broadcast.

Cet article examine la politique de production des émissions de la $\mathrm{BBC}$ pendant une période de croissance après la Deuxième guerre. Il explore notamment la représentation des femmes et des classes populaires, à la fois dans les émissions, et dans les publics imaginés par les équipes créatives.

\section{INDEX}

Mots-clés: BBC, années 1950, années 1960, fictions, femmes

Keywords: BBC, drama, women, 1950s, 1960s 